\title{
Plates and figures
}

\section{Plates}

1 Female supplicant before Catherine of Siena, BnF latin 10533, fol. $134 \mathrm{v}$ (Bibliothèque nationale de France)

2 Seal of Catherine Gronnaix, BnF Lorraine 231.157 (Bibliothèque nationale de France )

3 Parish church of St-Martin (Metz), exterior (Susannah Crowder)

4 Sculpted tabernacles and murals depicting scenes from the life of the Virgin, Notre Dame chapel, St-Martin (fab5669 / Wikimedia Commons)

5 Tabernacle detail: Virgo Lactans, Notre Dame chapel, St-Martin (Susannah Crowder)

6 Scenes from the life of the Virgin, St-Martin (Aidan McRae Thomson)

7 Annunciation window, scenes from the life of the Virgin, St-Martin (public domain)

8 Joan of Arc and the coronation of Charles VII, St-Martin (Metz), 1910, detail (public domain)

\section{Figures}

2.1 'Je, Katheryne le Gronnaix', BnF Lorraine 231.158, with inset detail (Bibliothèque nationale de France)

3.1 Map of Metz (Susannah Crowder, drawn by Don Shewan)

3.2 Interior plan, St-Martin (Susannah Crowder, drawn by Don Shewan)

3.3 Map of Metz, detail of St-Martin area (Susannah Crowder, drawn by Don Shewan) 
4.1 Plan of Celestines, 1372, Metz BM 833, p. 2

(Susannah Crowder)

148

4.2 Plan of Celestines, 1376, Metz BM 833, p. 12

(Susannah Crowder)

4.3 Plan of Celestines, c. 1419, Metz BM 833, pp. 88-9

(Susannah Crowder) 